\title{
Biocompatible Silver Nanoparticle-Modified Natural Diatomite with Anti-Infective Property
}

\author{
Haolin Sun $\left(\mathbb{D},{ }^{1,2}\right.$ Xiaoxiao Wen $\left(\mathbb{D},{ }^{3}\right.$ Xiang Zhang $\left(\mathbb{D},{ }^{3}\right.$ Donglei Wei $\mathbb{D}^{3},{ }^{3}$ Huilin Yang $\mathbb{D}$, ${ }^{2,3}$ \\ Chunde $\operatorname{Li}\left(\mathbb{C}^{1},{ }^{1}\right.$ and Lei Yang $\mathbb{1}^{2,3}$ \\ ${ }^{1}$ Department of Orthopedic, Peking University First Hospital, Beijing 100034, China \\ ${ }^{2}$ International Research Center for Translational Orthopaedics (IRCTO), Soochow University, Suzhou 215006, China \\ ${ }^{3}$ Institute of Orthopaedics and Department of Orthopaedics, The First Affiliated Hospital, Soochow University, Suzhou 215006, China \\ Correspondence should be addressed to Chunde Li; lichunde@medmail.com.cn and Lei Yang; yleibrown@gmail.com
}

Received 12 November 2017; Revised 17 January 2018; Accepted 22 January 2018; Published 22 February 2018

Academic Editor: Piersandro Pallavicini

Copyright (C) 2018 Haolin Sun et al. This is an open access article distributed under the Creative Commons Attribution License, which permits unrestricted use, distribution, and reproduction in any medium, provided the original work is properly cited.

\begin{abstract}
Nanosilver as an alternative antibacterial agent of antibiotics has been researched for possible applications in various orthopedic implants. However, it is imperative to achieve controllable release of $\mathrm{Ag}^{+}$to reduce its cytotoxic effect on normal tissue. Here, a nanosilver release system that has potential to be used in anti-infective bone cement was reported. Nanosilver modified diatomite was developed through the reaction of Tollens' reagent to improve the antibacterial effect and natural diatomite was used as the carrier of $\mathrm{Ag}^{+}$ions for controlled release. Cytotoxicity and the antibacterial activities of the nanosilver release system were characterized. After 3 days, the NIH3T3 cells cultured in the extract of nanosilver modified diatomite with an initial concentration of $0.5 \mathrm{mg} / \mathrm{ml}$ showed better cell viability than cells cultured in $\alpha$-MEM. The density of MC3T3-E1 cells cultured in the extract of nanosilver modified diatomite at the same concentration did not differ significantly from the density of cells cultured in $\alpha$-MEM. The nanosilver modified diatomite exhibited antibacterial effect against $E$. coli and $S$. aureus when the concentration was higher than $0.5 \mathrm{mg} / \mathrm{ml}$. With appropriate selection of $\mathrm{Ag}^{+}$concentration, the nanosilver modified diatomite is promising for improving the antibacterial effect while not affecting the biocompatibility of reinforced calcium phosphate bone cement.
\end{abstract}

\section{Introduction}

Bone cement is widely used by orthopedic surgeons to help secure arthroplasty implants, to fill bone voids, and to treat vertebral compression fractures $[1,2]$. However, in these procedures, deep wound infection, usually caused by Staphylococcus spp. and/or Propionibacterium acnes, is a devastating complication [3,4]. The usage of antibiotic-loaded bone cement (ALBC) is a well-accepted strategy in the treatment of specific infections [5, 6]. However, it remains controversial for preventive applications due to the result which may not warrant the additional costs of ALBC and the limited efficiency as a result of bacterial resistance to antibiotics [7]. Therefore, in order to develop more effective strategies to combat infection, nanosilver has been introduced into bone cements as an agent against multiresistant bacteria to enhance antibacterial property, aiming to replace the currently used ALBC $[8,9]$. Nanosilver has been used in many studies to treat wound infection and proved to be effective biocide against drug-resistant bacteria [10-12]. In order to meet the requirement of new bone formation, bone cement containing nanosilver should also possess good biocompatibility and preferably osteoconductivity. However, high concentration of nanosilver has been demonstrated to be cytotoxic and genotoxic to mammalian cells [13]. So achieving controllable release of nanosilver and adjusting the interaction between nanosilver and its release carriers to reduce cytotoxic effect become necessary.

In our previous study, diatomite particles have been used as a reinforcing second phase to enhance the mechanical strength of calcium phosphate bone cement (CPC) [14]. The structure of diatomite is highly porous with pore sizes about 50-200 nm, which allows the binding of other molecules $[15,16]$. In recent years, diatomite with good biocompatibility has been exploited as carrier for drug/molecule delivery applications due to the unique properties such as highly 
porous structure, high surface area, and readily modifiable surface functionalities, demonstrating high potential in biotechnological applications [16-19]. For example, diatomite has been recently conjugated with peptide and loaded with small interfering RNA for B-cell lymphoma therapy [20]. In addition, metal-modified diatomites have been developed for the deposition of gold or palladium nanoparticles [21]. Based on this favorable property and potential, in this study, diatomite particles were further developed as release carriers for loading and controlled release of nanosilver particles and such nanosilver incorporated diatomite is expected to improve the anti-infective and mechanical properties of CPC. Here, the toxicity and antibacterial properties of diatomite particles loaded with different concentrations of nanosliver were systematically evaluated by various cell assays. Based on these results, the current study reports an optimized formula of nanosilver modified diatomite (nAgDT) with both biocompatibility and anti-infective capacity.

\section{Materials and Methods}

2.1. Preparation and Characterization of $n A g D T$. Diatomite particles with different sizes prepared in previous study [6] were added into Tollens' reagent which was prepared by adding 25 28\% $\mathrm{NH}_{3} \cdot \mathrm{H}_{2} \mathrm{O}$ solution into the $0.1 \mathrm{M} \mathrm{AgNO}_{3}$ solution. After stirring for $30 \mathrm{mins}, 0.2 \mathrm{M}$ glucose solution was added to react for an hour at room temperature. After the reaction was completed, particles from a resultant black turbid suspension was collected and rinsed in plenty of DI for 3 times. After that, the samples were dried for 24 hours at $60^{\circ} \mathrm{C}$ to collect the nAgDT particles.

The morphology of diatomite and nAgDT was observed by scanning electron microscopy (SEM, FEI QUANTA 250 , acceleration voltage of $20 \mathrm{kV}$ under a vacuum of 1.56 $\times 10^{-4} \mathrm{~Pa}$ ) with additional dispersive X-ray spectrometry (TEAM EDS, AMETEK) and the samples were sputtering coated with Au-Pd (Quorum Technologies, SC7620) before SEM examination. To rule out the possible effect of glucose residue on the material morphological study, the pure diatomite sample was also mixed with $0.2 \mathrm{M}$ glucose solution before examination.

Natural diatomite and nAgDT were analyzed by X-ray diffraction (XRD) using conditions of $40 \mathrm{kV} \mathrm{CuK} \alpha$ radiation at a scan speed of $2^{\circ} / \mathrm{min}$ (X-ray diffractometer APEX DUO, Bruker AXS).

To detect the $\mathrm{Ag}^{+}$release from the $\mathrm{nAgDT}$ in aqueous solution, nAgDT particles were mixed with DI water (at concentrations of $0.1,0.5,1,2.5$, and $5 \mathrm{mg} / \mathrm{ml}$ ) and the dilute was collected for inductively coupled plasma-atomic emission spectroscopy (ICP-AES, Varian) tests at $2 \mathrm{~h}, 6 \mathrm{~h}$, and $12 \mathrm{~h}$. The measurements were repeated 2 times for each sample.

2.2. Cytocompatibility Study. In vitro cytotoxicity of nAgDT was tested on NIH3T3 fibroblasts and MC3T3-E1 rat osteoblasts (Cell Resource Center, Shanghai Institutes for Biological Sciences, CAS), which were cultured in $\alpha$-MEM supplemented with $10 \%$ fetal bovine serum and $1 \%$ of penicillin/streptomycin at $37^{\circ} \mathrm{C}$ in a humidified $5 \% \mathrm{CO}_{2}$ atmosphere. Nanosilver modified diatomite particles were suspended in cell culture medium at concentrations of $0.1,0.5$, $1,2.5$, and $5 \mathrm{mg} / \mathrm{ml}$, respectively. After $12 \mathrm{~h}$, the suspensions were filtered to obtain the extract solutions. MC3T3-E1 cells were seeded in $200 \mu \mathrm{L}$ of each type of extract solution in 96-well plate at a density of 5,000 cells per well and cultured for $24 \mathrm{~h}$ and $72 \mathrm{~h}$. Normal cell culture medium was used as a control group. Cell proliferation was tested by commercial nonradioactive cell counting kit-8 (CCK8; Dojindo Laboratories, Kumamoto, Japan) according to the manufacturer's instructions. Cell test was repeated for 3 times $(n=3)$ and each type of extract solution had four replicas. In addition, MC3T3-E1 osteoblasts were cultured in $1 \mathrm{~mL}$ of $\mathrm{nAgDT}$ extract in a 24 -well plate at a density of $1 \times 10^{4}$ cells $/ \mathrm{cm}^{2}$. After $72 \mathrm{~h}$, adhered cells were stained with 4,6-diamidino-2-phenylindole (DAPI) and counted for proliferation density.

2.3. Bacterial Study. The bacterial study was performed by adding $100 \mu \mathrm{L}$ bacterial suspensions of Escherichia coli (E. coli) and Staphylococcus aureus (S. aureus) at densities of $10^{5}$ colony-forming unit (CFU) per $\mathrm{mL}$ into $50 \mathrm{~mL}$ suspension of $\mathrm{nAgDT}$ in PBS at concentrations of $0.1,0.5,1,2.5$, and $5 \mathrm{mg} / \mathrm{mL}$, respectively. According to the antibacterial testing standard (GB/T 21510-2008), nanosilica (particle size $\sim 100 \mathrm{~nm}$ ) was used as a control. After that, $1 \mathrm{~mL}$ of the mixed suspension incubated for $4 \mathrm{~h}$ in a shaker at $190 \mathrm{rpm}$ was transferred and inoculated on an agar plate at $37^{\circ} \mathrm{C}$. After cultured for $48 \mathrm{~h}$, the bacteria on agar plate were imaged.

2.4. Statistical Analysis. Results were expressed as mean \pm standard deviation (SD). Statistical analyses were conducted using one-way ANOVA with post hoc tests.

\section{Results and Discussion}

3.1. Characterization of $n A g D T$. Figure 1 shows the simplified fabrication process used to obtain nAgDT particles. The diskshaped diatomite particles with median size about $30 \mu \mathrm{m}$ which are completely cytocompatible were prepared by the methods described in our previous work [6]. These diatomite particles show hierarchical layer structure with multiple pores both inside and on the surface of the particle, which is beneficial for the adsorption of heavy metal ions from aqueous solution. Adding diatomite particles into Tollens' reagent with vigorous stirring allows the complete adsorption of $\mathrm{Ag}^{+}$ions. High concentrations of glucose can reduce $\mathrm{Ag}^{+}$ ions to metallic silver adsorbed on the diatomite particles.

Figures 2(a) and 2(b) show the SEM micrographs of morphology of diatomite and nAgDT particles, respectively. The surface of the diatomite was smooth but had some submicron-sized pores with uniform size distribution (Figures 2(a) and 2(c)). As shown in Figure 2(b), the silver nanoparticles can be clearly observed on the surface of the nAgDT and show spherical shape. Part of the silver nanoparticles filled in the pore space. The EDS results show that there were about 3.08 wt.\% of silver in the nAgDT particles. As shown by the SEM images at less magnification (Figure 2(d)), the silver nanoparticles distributed homogeneously on the 

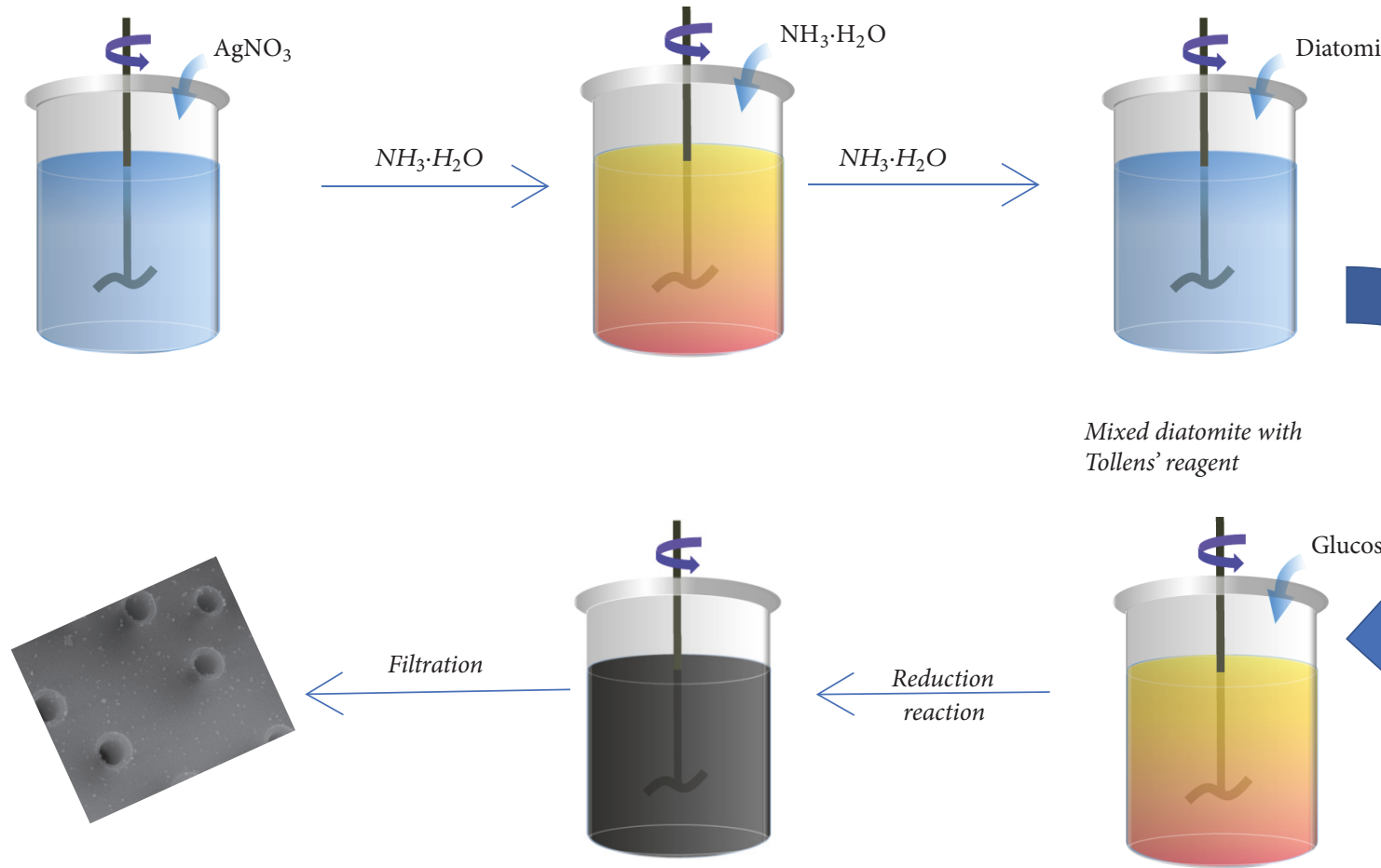

Mixed diatomite with
Tollens' reagent

FIgURE 1: Schematic showing the procedure used to prepare silver modified diatomite.

surface of diatomite. XRD results further demonstrated the existence of sliver. The XRD patterns of diatomite and $\mathrm{nAgDT}$ particles are illustrated in Figure 3. From the XRD patterns of $\mathrm{nAgDT}$, four new characteristic peaks appeared at $2 \theta$ values around $38^{\circ}, 44^{\circ}, 64^{\circ}$, and $77^{\circ}$ representing the 111 , 200, 220, and 311 crystal planes, which corresponded to crystallographic structure of silver nanoparticles [22].

The $\mathrm{Ag}^{+}$release behavior of different concentrations of $n A g D T$ was shown in Figure 4. The release kinetics of $\mathrm{Ag}^{+}$ depended on the concentration of samples. The total $\mathrm{Ag}^{+}$ contents released from the $0.1,0.5,1,2.5$, and $5 \mathrm{mg} / \mathrm{mL}$ samples after $12 \mathrm{~h}$ were $1.38,4.67,7.10,13.68$, and $24.83 \mathrm{mg} / \mathrm{L}$, respectively. The higher the concentration of $\mathrm{nAgDT}$, the greater the amount of $\mathrm{Ag}^{+}$ions released in the solution. The $\mathrm{Ag}^{+}$releasing amount from the $0.1 \mathrm{mg} / \mathrm{mL}$ samples started to level off and reached a plateau after about $2 \mathrm{~h}$, in contrast to $6 \mathrm{~h}$ for 0.5 and $1 \mathrm{mg} / \mathrm{mL}$ samples. There was still sustained release of $\mathrm{Ag}^{+}$after $12 \mathrm{~h}$ in the 2.5 and $5 \mathrm{mg} / \mathrm{mL}$ samples. As $\mathrm{nAgDT}$ particles were dispersed into distilled water, nanosilver adsorbed on diatomite reacted with dissolved $\mathrm{O}_{2}$ and was mediated by protons to produce $\mathrm{Ag}^{+}$ions [23]. When the redox reaction became an equilibrium reaction, the amount of released $\mathrm{Ag}^{+}$ions reached the steady value. The $\mathrm{Ag}^{+}$release was slowed down with a gradual increase of release concentration of $\mathrm{Ag}^{+}$over time, which indicates that $\mathrm{Ag}^{+}$could be released in a controllable way.

3.2. Cytocompatibility of $n A g D T$. In order to evaluate the cytotoxicity of nanosilver modified diatomite, NIH3T3 fibroblasts and MC3T3-E1 osteoblasts were cultured in the extracts of different concentrations of samples, respectively. Results of NIH3T3 cell proliferation in nAgDT extracts are shown in Figure 5. All tested samples after culturing for 1 and 3 days, as expected, showed dose-dependent decreases in both osteoblast and fibroblast proliferation. The 0.1 and $0.5 \mathrm{mg} / \mathrm{mL}$ of nAgDT did not show obvious cytotoxicity with NIH3T3 cells but even better cell viability than control group after culturing for 3 days. When the concentration of nAgDT increased to $1,2.5$, and $5 \mathrm{mg} / \mathrm{mL}$, the extract solution showed obvious cytotoxicity. The $\mathrm{Ag}^{+}$ions in the extract of $\mathrm{nAgDT}$ at concentration of more than $10 \mathrm{mg} / \mathrm{mL}$ significantly inhibited NIH3T3 cell proliferation. In order to further confirm the biocompatibility of nAgDT with MC3T3-E1 cells, the nucleus of attached cells after culture for 3 days was stained with DAPI and fluorescently imaged. Then their density was calculated (Figure 6). The cell density of the 0.1 and $0.5 \mathrm{mg} / \mathrm{mL}$ groups was similar to the control group, which had no significant difference. When the concentration of $\mathrm{nAgDT}$ was higher than $1 \mathrm{mg} / \mathrm{mL}$, the number of MC3T3-E1 cells was reduced to a large extent. As shown in the fluorescent images (Figures 6(b)-6(g)), the nucleus of MC3T3-E1 cells stained with DAPI in $0.1,0.5 \mathrm{mg} / \mathrm{mL}$ and control groups were similar in their number and distribution. While, in the extract of $\mathrm{nAgDT}$ at higher concentration, there were significantly fewer cells. The result also showed the similar dose-dependent cytotoxicity of $\mathrm{nAgDT}$, which confirmed the result in Figure 5 that $1 \mathrm{mg} / \mathrm{mL}$ was the threshold concentration to inhibit cells proliferation. Meanwhile, the dose-dependent cytotoxicity pattern was consistent with studies on other types of cells, such as L929, HBE, and A549 cells [24, 25]. The possible explanation for the cytotoxicity of high concentration of $\mathrm{nAgDT}$ is that the generation of reactive oxygen species and suppression of reduced glutathione induced by nanosilver cause DNA damage and cellular apoptosis $[26,27]$. 


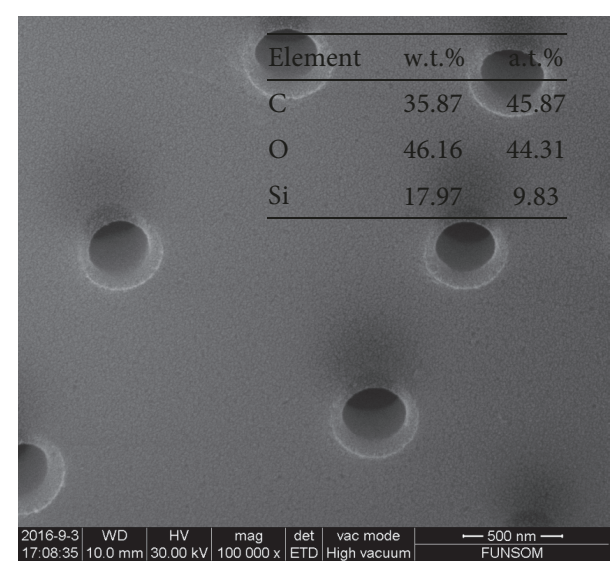

(a)

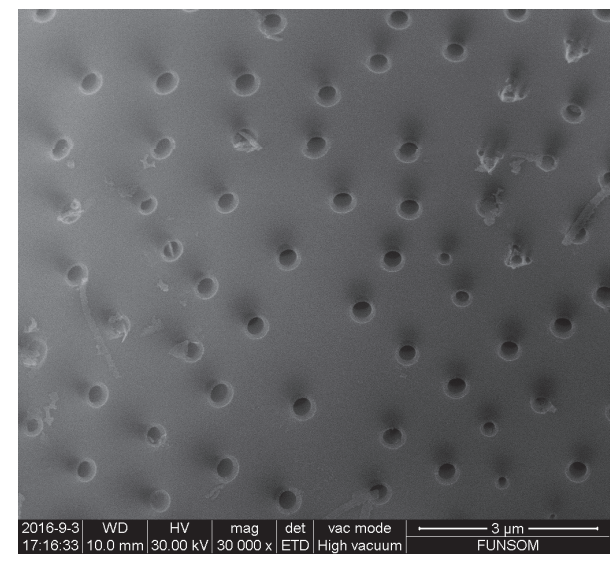

(c)

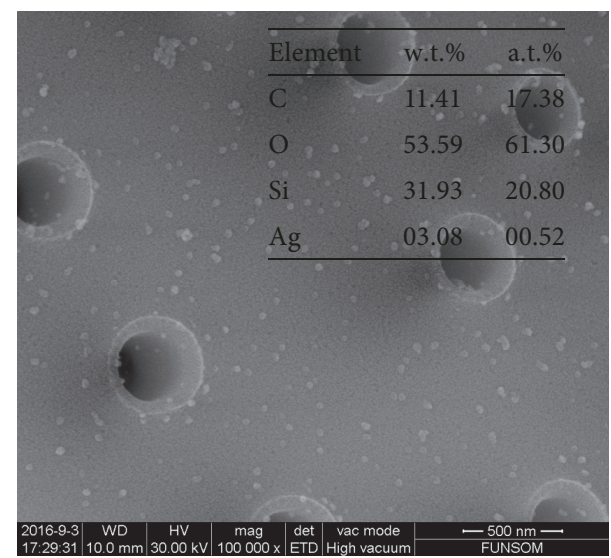

(b)

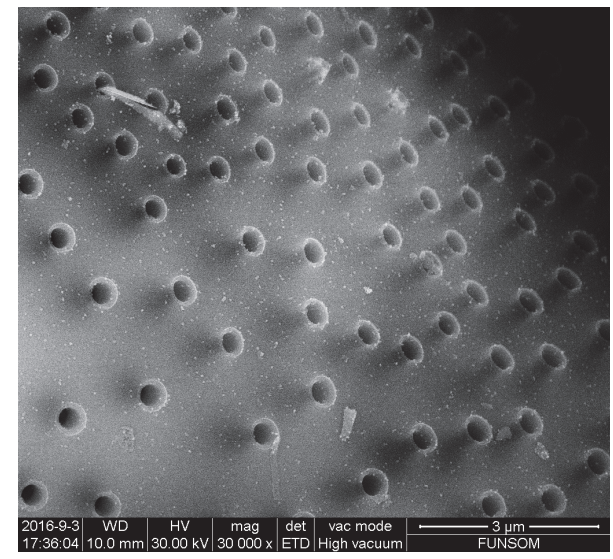

(d)

FIgURE 2: SEM images of the diatomite (a, c) and nAgDT (b, d) at different magnification. Corresponding EDS results are shown in (a) and (b).

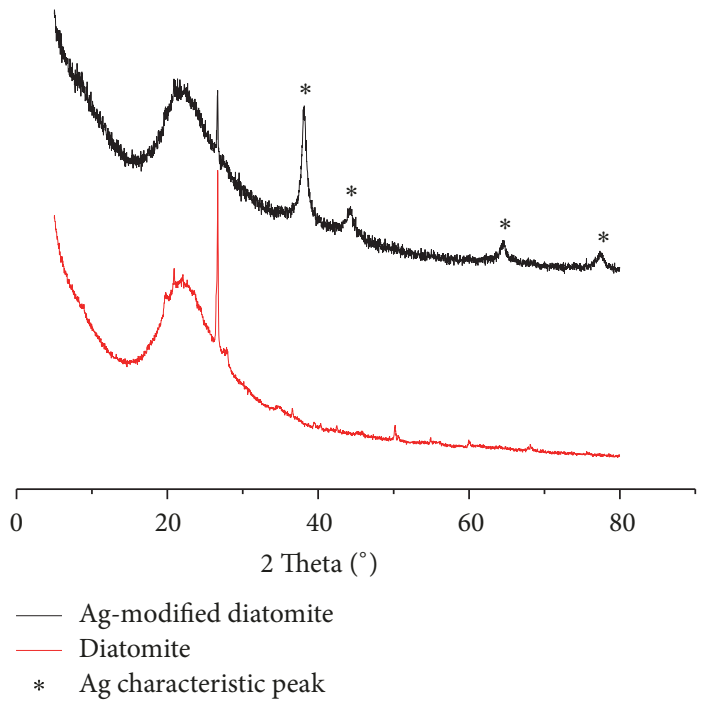

FIGURE 3: XRD patterns of diatomite and nAgDT. 


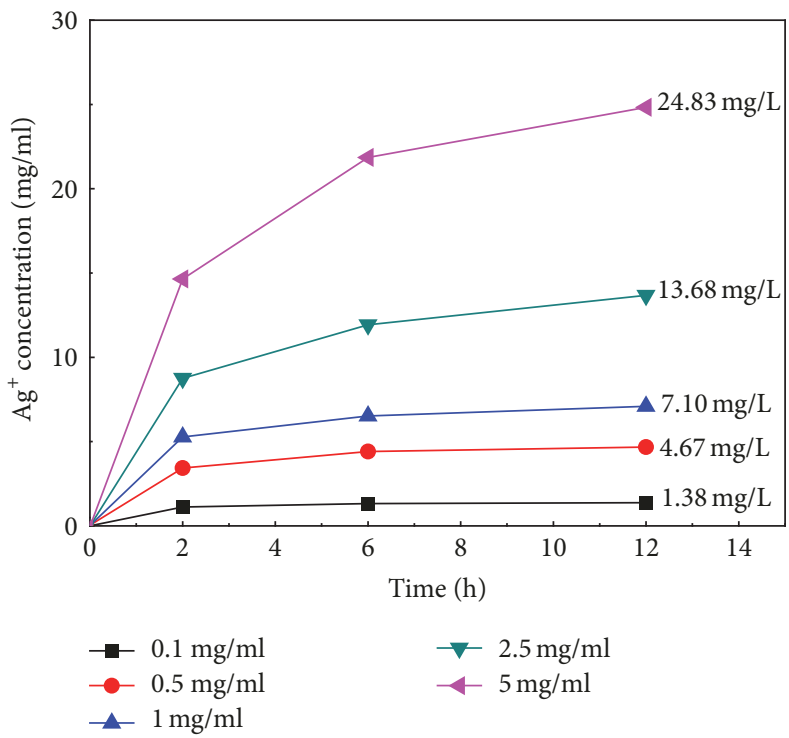

Figure 4: Results of $\mathrm{Ag}^{+}$release from different nAgDT suspensions for $12 \mathrm{~h}$.
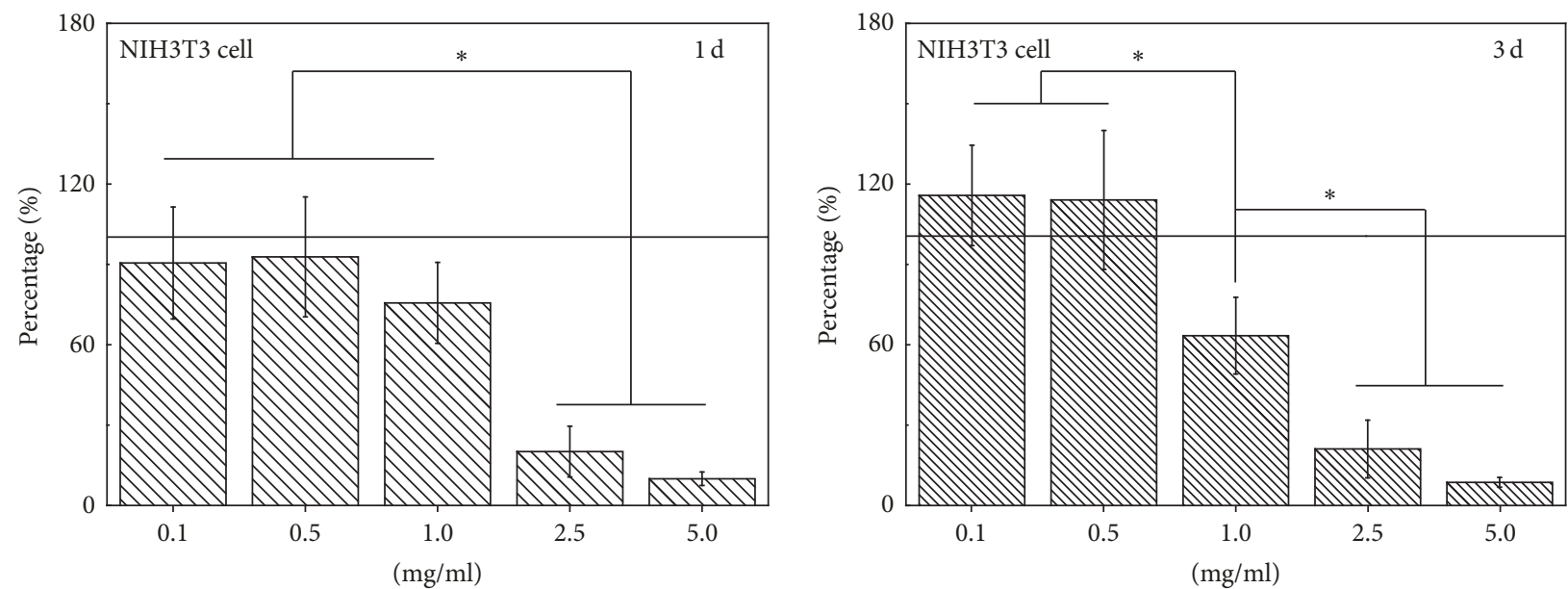

FIGURE 5: Results of proliferation rate of NIH3T3 cells cultured in extract of nAgDT after 1 day and 3 days. Proliferation rate of cells cultured in $\alpha$-MEM was set to 1 and indicated by the lines. All the results were normalized to corresponding results. ${ }^{*} p<0.01$.

3.3. Antibacterial Properties of $n A g D T$. To evaluate the antibacterial properties of the nAgDT, E. coli and S. aureus, which are common pathogens of infection, were cultured with $\mathrm{nAgDT}$ suspension. As shown in Figure 7, the nanosilica with bacterial group and pure bacterial group showed that the nanosilica particles could not inhibit the bacterial growth. It can be observed that the numbers of bacterial colony altered depending on different concentrations of $\mathrm{nAgDT}$. $0.1 \mathrm{mg} / \mathrm{mL}$ of $\mathrm{nAgDT}$ had no effect on preventing the growth of bacteria. However, when the concentration was increased to $0.5 \mathrm{mg} / \mathrm{mL}$, there were only few $E$. coli colonies formed on the plate. It could hardly observe the $S$. aureus colonies with $0.5 \mathrm{mg} / \mathrm{mL} \mathrm{nAgDT}$ suspension. The higher concentration of $\mathrm{nAgDT}$ further reduced the number of bacteria. There was no bacterial surviving on the plate with $5 \mathrm{mg} / \mathrm{ml}$ nanosilver modified diatomite. The sensitivity of $S$. aureus to $\mathrm{nAgDT}$ was greater than $E$. coli, which is consistent with previous research [25]. For the antibacterial property, the
nAgDT also showed the dose-dependent characterization, as the higher concentration of nAgDT showed significantly better bactericidal effect. As shown in Figure 4, there was more silver released in the $\mathrm{nAgDT}$ suspension at higher concentration. For the antibacterial property of $\mathrm{nAgDT}$, silver release plays an important role. $\mathrm{Ag}^{+}$ions released in the $\mathrm{nAgDT}$ suspension can penetrate into bacterial cells and then destroy the replication ability of the DNA, finally resulting in bacterial death. Moreover, nanosilver particles in $\mathrm{nAgDT}$ can attack the respiratory chain and then induce bacterial death [28]. When the concentration is not less than $0.5 \mathrm{mg} / \mathrm{ml}$, the $\mathrm{nAgDT}$ can possess satisfactory antibacterial property.

\section{Conclusions}

The $\mathrm{nAgDT}$ has been developed through the reaction of Tollens' reagent, by which silver particles were uniformly deposited on the surface of diatomite. Also $\mathrm{Ag}^{+}$ions could 


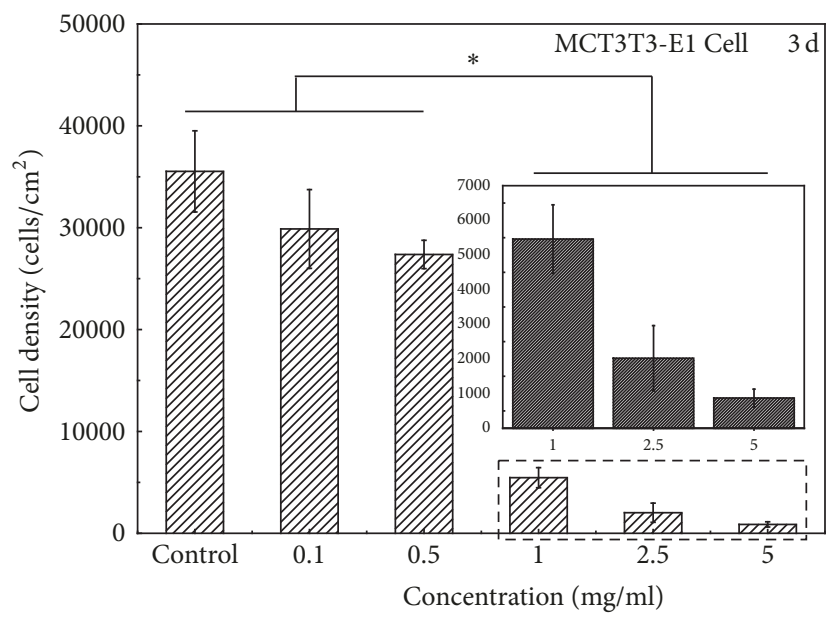

(a)

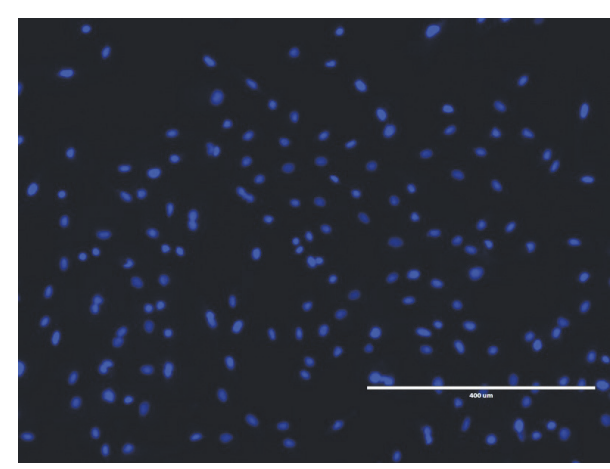

(b)

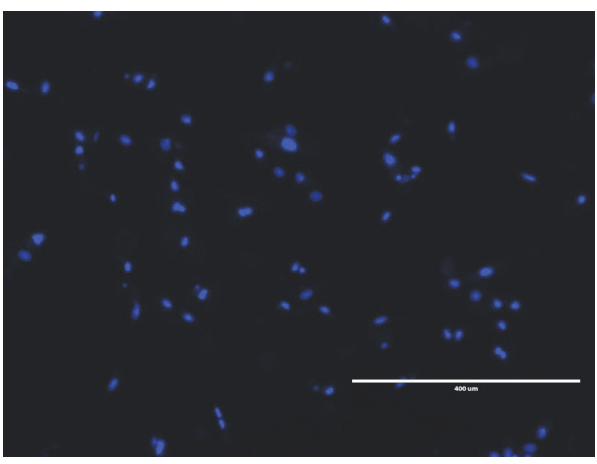

(d)

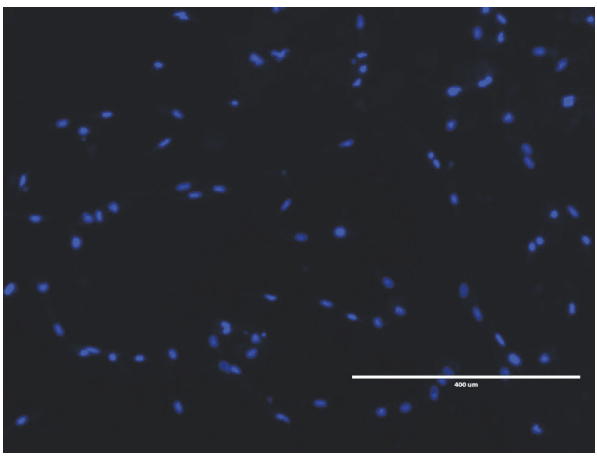

(f)

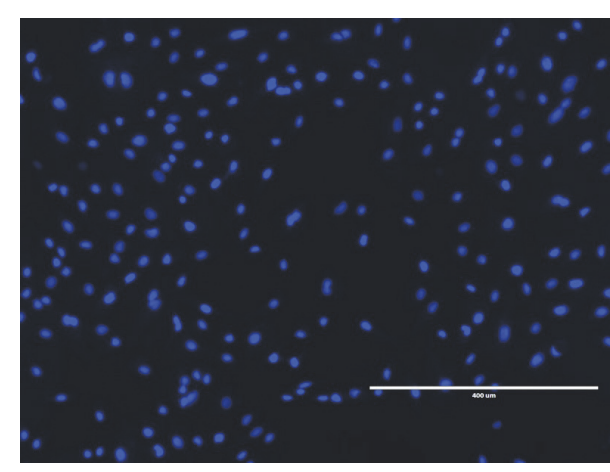

(c)

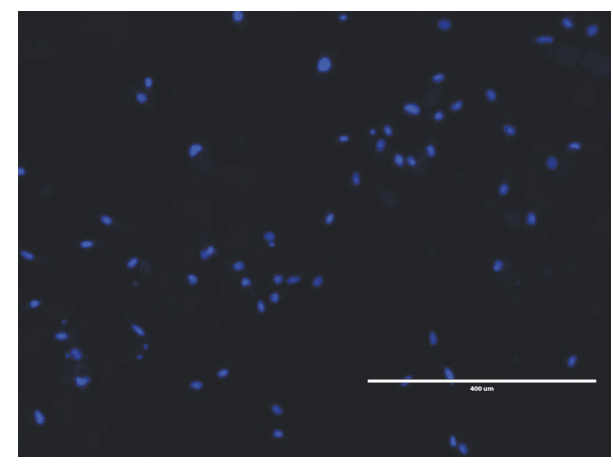

(e)

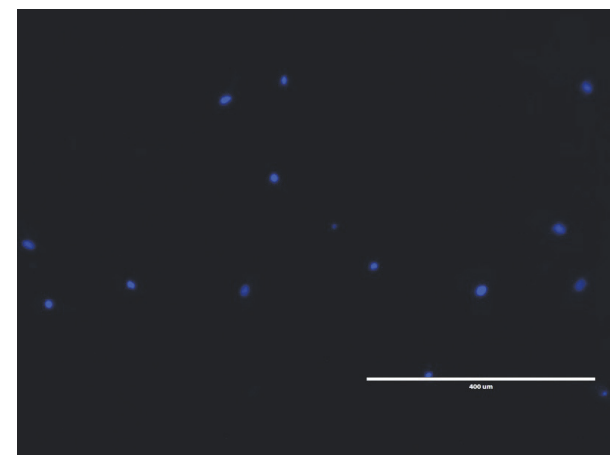

(g)

FIGURE 6: Results of cell density of MC3T3-E1 cultured in extract of nAgDT for 3 days (a) and the images of DAPI-stained cells cultured in $\alpha$-MEM control (b) and extracts of nAgDT at concentration of 0.1 (c), 0.5 (d), 1 (e), 2.5 (f), and 5 (g) mg/mL, respectively. Scale bar $=200 \mu \mathrm{m}$. ${ }^{*} p<0.01$. 


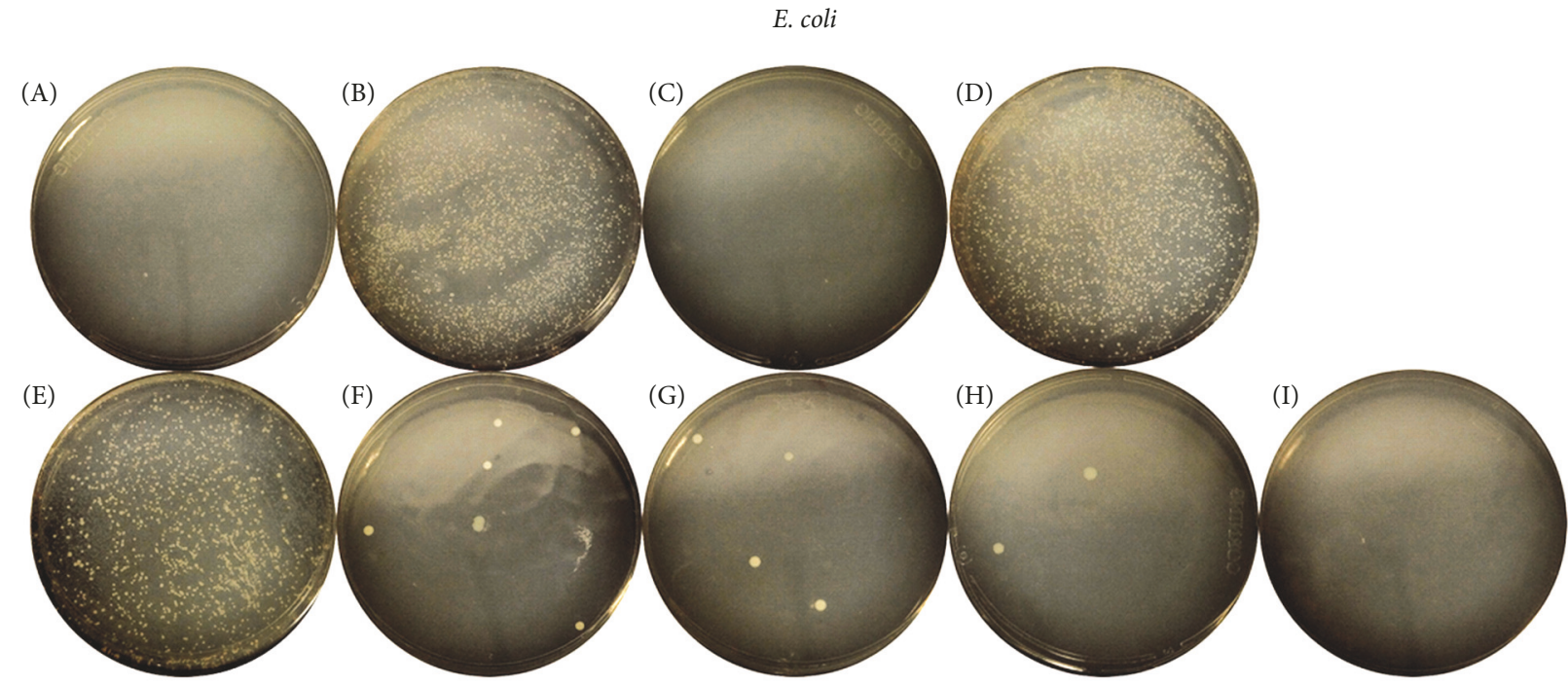

(a)

S. aureus
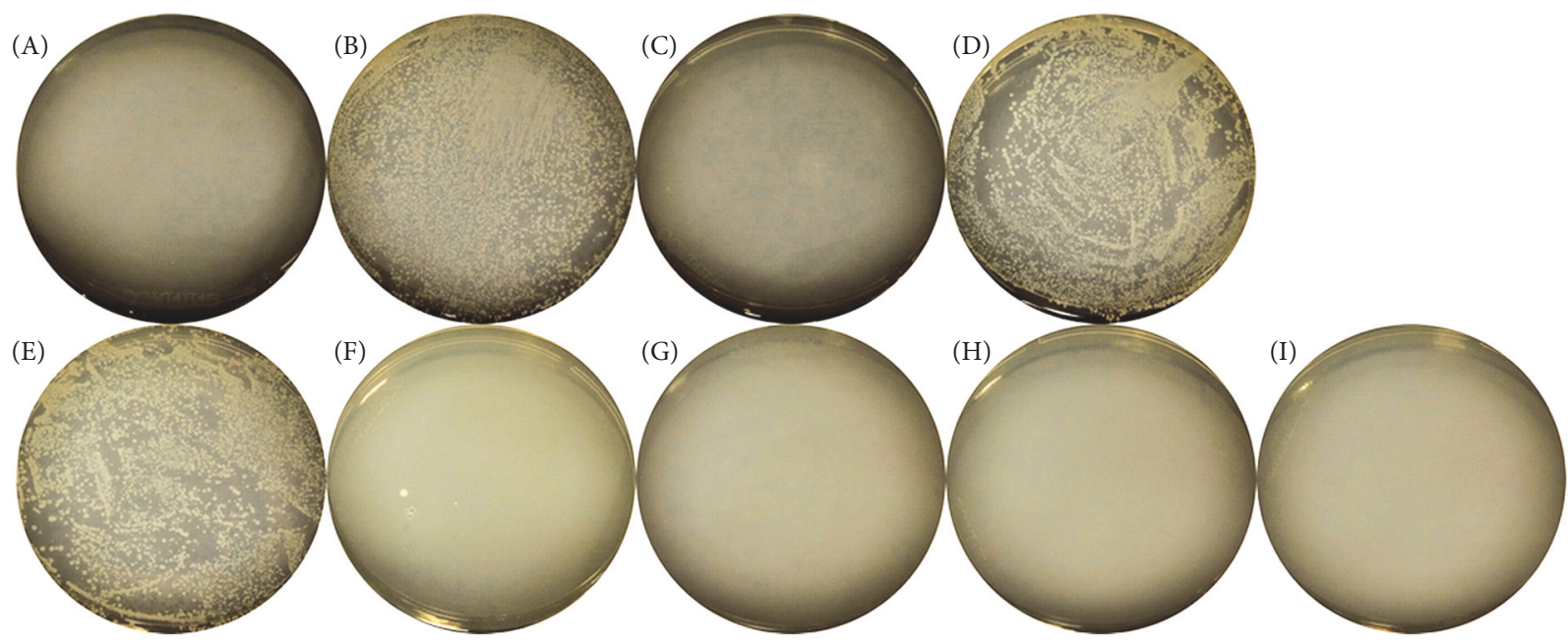

(b)

FIgURE 7: Antibacterial effect of different samples against E. coli (a) and S. aureus (b). Images show agar plates inoculated with $1 \mathrm{~mL}$ of PBS (A), bacterial suspension in PBS (B), nanosilica solutions (C), bacterial suspension in nanosilica solutions (D), and bacterial suspension in nAgDT solutions at concentration of $0.1(\mathrm{E}), 0.5(\mathrm{~F}), 1(\mathrm{G}), 2.5(\mathrm{H})$, and $5(\mathrm{I}) \mathrm{mg} / \mathrm{mL}$, respectively.

be released in a controllable manner from the $\mathrm{nAgDT}$. More importantly, the $\mathrm{nAgDT}$ with a concentration of $0.5 \mathrm{mg} / \mathrm{mL}$ exhibited excellent antibacterial effects against both $E$. coli and $S$. aureus without showing significant cytotoxicity to NIH3T3 and MC3T3 cells. This new material can be used in bone cement to improve its antibacterial effect while not affecting the biocompatibility.

\section{Conflicts of Interest}

The authors declare that there are no conflicts of interest regarding the publication of this article.

\section{Authors' Contributions}

Haolin Sun, Xiaoxiao Wen, and Xiang Zhang contribute equally to this work.

\section{Acknowledgments}

The authors thank National Natural Science Foundation of China (5162184, 81622032, and 51525101), the Scientific Research Foundation for the Returned Overseas Chinese Scholar $(2015,311)$, the Youth Clinical Research Project of Peking University First Hospital (2017CR06), and Jiangsu 
Innovation and Entrepreneurship Program for supporting this work.

\section{References}

[1] G. X. Ni, K. Y. Chiu, W. W. Lu et al., "Strontium-containing hydroxyapatite bioactive bone cement in revision hip arthroplasty," Biomaterials, vol. 27, no. 24, pp. 4348-4355, 2006.

[2] M. Nakano, N. Hirano, K. Matsuura et al., "Percutaneous transpedicular vertebroplasty with calcium phosphate cement in the treatment of osteoporotic vertebral compression and burst fractures," Journal of Neurosurgery, vol. 97, no. 3, pp. 287293, 2002.

[3] N. Dunne, J. Hill, P. McAfee et al., "In vitro study of the efficacy of acrylic bone cement loaded with supplementary amounts of gentamicin: Effect on mechanical properties, antibiotic release, and biofilm formation," Acta Orthopaedica, vol. 78, no. 6, pp. 774-785, 2007.

[4] Q. Cui, W. M. Mihalko, J. S. Shields, M. Ries, and K. J. Saleh, "Antibiotic-impregnated cement spacers for the treatment of infection associated with total hip or knee arthroplasty," The Journal of Bone \& Joint Surgery, vol. 89, no. 4, pp. 871-882, 2007.

[5] J. G. E. Hendriks, J. R. Van Horn, H. C. Van Der Mei, and H. J. Busscher, "Backgrounds of antibiotic-loaded bone cement and prosthesis-related infection," Biomaterials, vol. 25, no. 3, pp. 545-556, 2004.

[6] A. D. Hanssen and M. J. Spangehl, "Practical applications of antibiotic-loaded bone cement for treatment of infected joint replacements," Clinical Orthopaedics and Related Research, no. 427, pp. 79-85, 2004.

[7] H. van de Belt, D. Neut, W. Schenk, J. R. van Horn, H. C. van der Mei, and H. J. Busscher, "Infection of orthopedic implants and the use of antibiotic-loaded bone cements," Acta Orthopaedica, vol. 72, no. 6, pp. 557-571, 2001.

[8] V. Alt, T. Bechert, P. Steinrücke et al., "An in vitro assessment of the antibacterial properties and cytotoxicity of nanoparticulate silver bone cement," Biomaterials, vol. 25, no. 18, pp. 4383-4391, 2004.

[9] N. Zhang, M. A. S. Melo, J. M. Antonucci et al., "Novel dental cement to combat biofilms and reduce acids for orthodontic applications to avoid enamel demineralization," Materials, vol. 9, no. 6, article no. 413, 2016.

[10] H. H. Lara, N. V. Ayala-Núñez, L. C. I. del Turrent, and C. R. Padilla, "Bactericidal effect of silver nanoparticles against multidrug-resistant bacteria," World Journal of Microbiology and Biotechnology, vol. 26, no. 4, pp. 615-621, 2010.

[11] B. S. Anisha, R. Biswas, K. P. Chennazhi, and R. Jayakumar, "Chitosan-hyaluronic acid/nano silver composite sponges for drug resistant bacteria infected diabetic wounds," International Journal of Biological Macromolecules, vol. 62, pp. 310-320, 2013.

[12] K. Madhumathi, P. T. S. Kumar, S. Abhilash et al., "Development of novel chitin/nanosilver composite scaffolds for wound dressing applications," Journal of Materials Science: Materials in Medicine, vol. 21, no. 2, pp. 807-813, 2010.

[13] P. V. AshaRani, G. L. K. Mun, M. P. Hande, and S. Valiyaveettil, "Cytotoxicity and genotoxicity of silver nanoparticles in human cells," ACS Nano, vol. 3, no. 2, pp. 279-290, 2009.

[14] X. Zhang, H. Yang, S. Li, G. Qin, and L. Yang, "Natural diatomite particles: Size-, dose- and shape- dependent cytotoxicity and reinforcing effect on injectable bone cement," Journal of Materials Science and Technology, 2017.
[15] O. Şan, R. Gören, and C. Özgür, "Purification of diatomite powder by acid leaching for use in fabrication of porous ceramics," International Journal of Mineral Processing, vol. 93, no. 1, pp. 6-10, 2009.

[16] I. Rea, N. M. Martucci, L. De Stefano et al., "Diatomite biosilica nanocarriers for siRNA transport inside cancer cells," Biochimica et Biophysica Acta (BBA) - General Subjects, vol. 1840, no. 12, pp. 3393-3403, 2014.

[17] M. S. Aw, S. Simovic, Y. Yu, J. Addai-Mensah, and D. Losic, "Porous silica microshells from diatoms as biocarrier for drug delivery applications," Powder Technology, vol. 223, pp. 52-58, 2012.

[18] I. Rea, M. Terracciano, and L. De Stefano, "Synthetic vs Natural: Diatoms Bioderived Porous Materials for the Next Generation of Healthcare Nanodevices," Advanced Healthcare Materials, vol. 6, no. 3, Article ID 1601125, 2017.

[19] S. Maher, T. Kumeria, Y. Wang et al., "From The Mine to Cancer Therapy: Natural and Biodegradable Theranostic Silicon Nanocarriers from Diatoms for Sustained Delivery of Chemotherapeutics," Advanced Healthcare Materials, vol. 5, no. 20, pp. 2667-2678, 2016.

[20] N. M. Martucci, N. Migliaccio, I. Ruggiero et al., "Nanoparticlebased strategy for personalized B-cell lymphoma therapy," International Journal of Nanomedicine, vol. 11, pp. 6089-6101, 2016.

[21] J. Jin, C. Zheng, and H. Yang, "Natural diatomite modified as novel hydrogen storage material," Functional Materials Letters, vol. 7, no. 3, Article ID 1450027, 2014.

[22] M. Montazer, F. Alimohammadi, A. Shamei, and M. K. Rahimi, "In situ synthesis of nano silver on cotton using Tollens' reagent," Carbohydrate Polymers, vol. 87, no. 2, pp. 1706-1712, 2012.

[23] J. Liu and R. H. Hurt, "Ion release kinetics and particle persistence in aqueous nano-silver colloids," Environmental Science \& Technology, vol. 44, no. 6, pp. 2169-2175, 2010.

[24] H. Peng, X. Zhang, Y. Wei et al., "Cytotoxicity of silver nanoparticles in human embryonic stem cell-derived fibroblasts and an L-929 cell line," Journal of Nanomaterials, vol. 2012, Article ID 160145, 9 pages, 2012.

[25] L. Ma, W. Su, J.-X. Liu et al., "Optimization for extracellular biosynthesis of silver nanoparticles by Penicillium aculeatum Sul and their antimicrobial activity and cytotoxic effect compared with silver ions," Materials Science Engineering CMaterials for Biological Applications, vol. 77, pp. 963-971, 2017.

[26] M. V. D. Z. Park, A. M. Neigh, J. P. Vermeulen et al., "The effect of particle size on the cytotoxicity, inflammation, developmental toxicity and genotoxicity of silver nanoparticles," Biomaterials, vol. 32, no. 36, pp. 9810-9817, 2011.

[27] M. J. Piao, K. A. Kang, I. K. Lee et al., "Silver nanoparticles induce oxidative cell damage in human liver cells through inhibition of reduced glutathione and induction of mitochondriainvolved apoptosis," Toxicology Letters, vol. 201, no. 1, pp. 92100, 2011.

[28] M. Rai, A. Yadav, and A. Gade, "Silver nanoparticles as a new generation of antimicrobials," Biotechnology Advances, vol. 27, no. 1, pp. 76-83, 2009. 


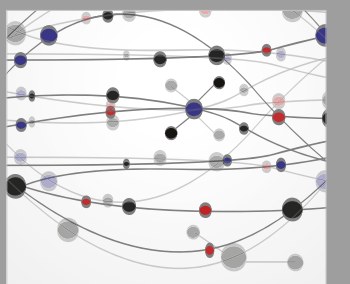

The Scientific World Journal
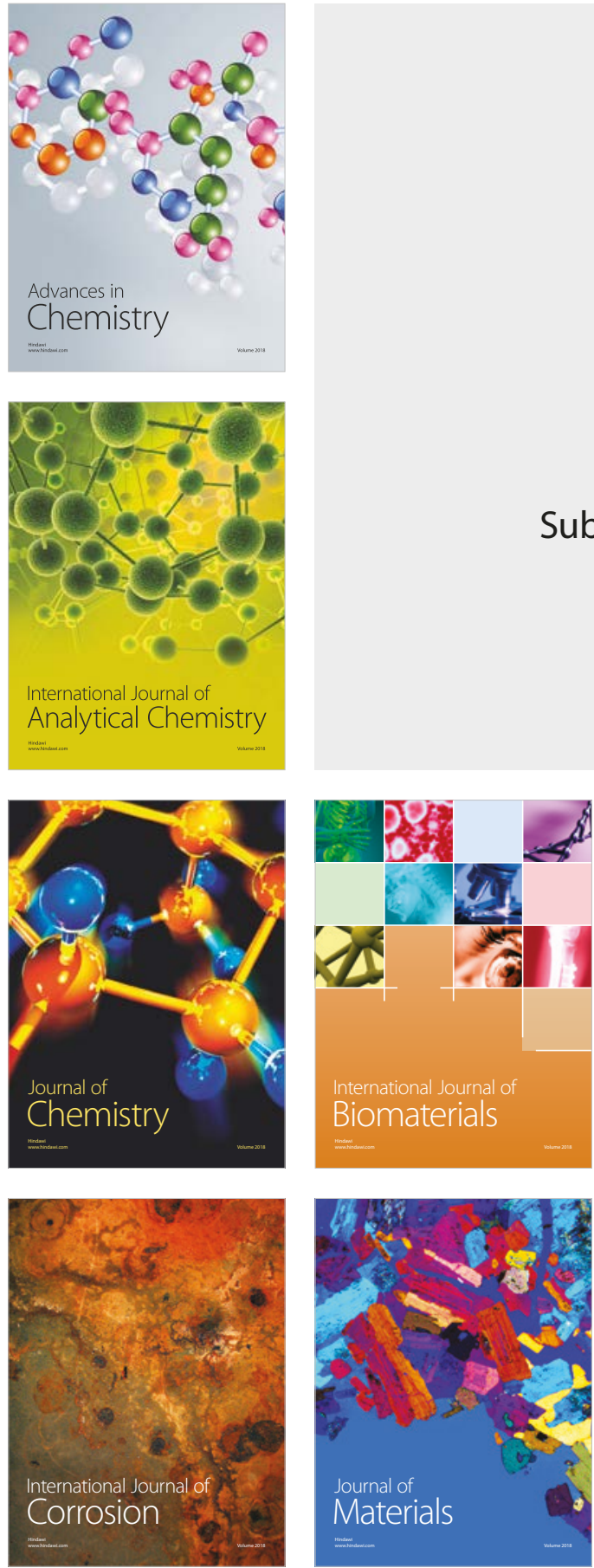

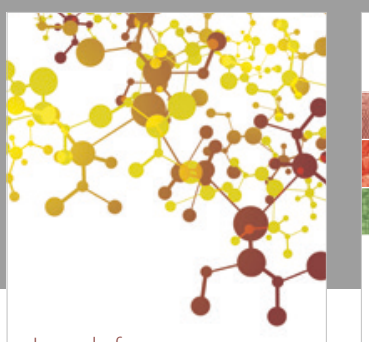

Journal of

Applied Chemistry
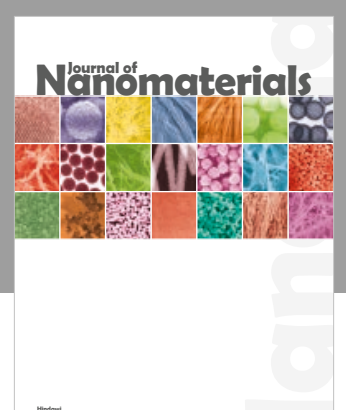

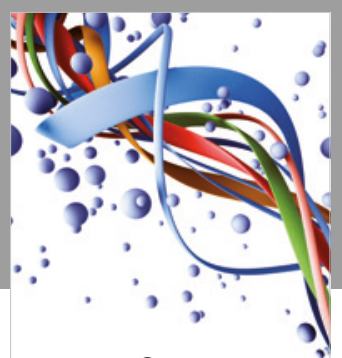

Scientifica

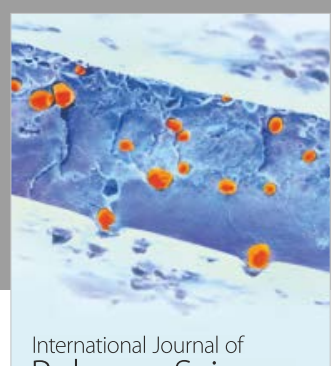

Polymer Science

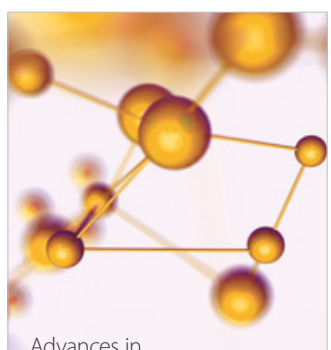

Physical Chemistry
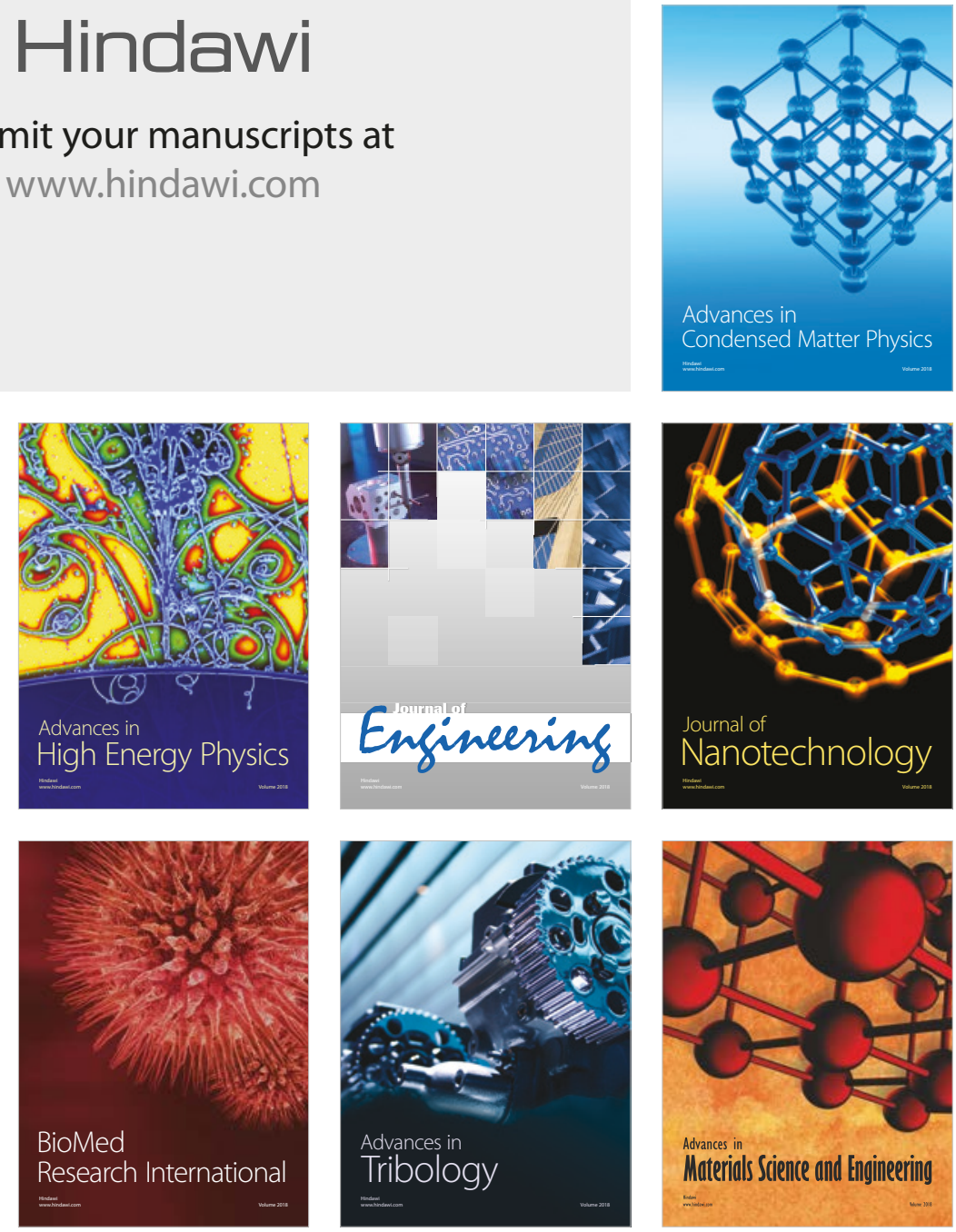